\title{
APPROACH TO REFURBISHMENT OF TIMBER PRESCHOOL BUILDINGS WITH A VIEW ON ENERGY AND ECONOMIC EFFICIENCY
}

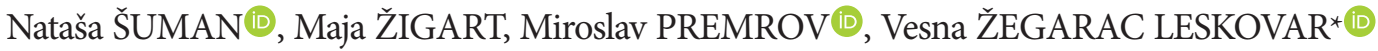 \\ Faculty of Civil Engineering, Transportation Engineering and Architecture, \\ University of Maribor, Maribor, Slovenia
}

Received 29 August 2018; accepted 30 October 2018

\begin{abstract}
The refurbishment of educational buildings usually involves a variety of measures aiming at reducing energy demands and improving building functionality to achieve higher living comfort. This paper aims to develop an approach for determination of comprehensive refurbishment strategy upon existing preschool buildings in Slovenia from the aspects of energy and economic efficiency. The main idea of the approach is to separate and individually analyse the investments into those related to energy efficiency improvements and those related to improvements of building functional quality through the step-by-step evaluation of individual measures. The proposed approach was applied on the case study of the existing timber preschool building in the city of Maribor. Generally, the highest energy savings are detected only in the case of combination of multiple renovation measures. Moreover, the economic indicators show low efficiency for almost all measures if they are treated separately. Additionally, the analysis reveals that certain measures are totally inefficient in terms of energy, yet they are highly beneficial from the viewpoint of building functional quality, which indicates the importance of the multi-perspective assessment of renovation process. The conclusions of this study can be implemented to similar building types and construction ages in similar climatic and economic environments.
\end{abstract}

Keywords: educational buildings, timber buildings, energy renovation, functional improvement, energy efficiency, cost of conserved energy.

\section{Introduction}

Built environment is considered as a focal point of socioeconomic human activities. A predominant part of our daytime being spent inside buildings makes living comfort vital to well-being and work effectiveness of their users. The living environment is an important factor especially for preschool children who are in the early stages of their development, and thus it influences their welfare and growth (Yun et al., 2014; Mijakowski \& Sowa, 2017). The building quality assessed by a set of various parameters with the most general ones attributed to functionality and safety along with other criteria related to thermal comfort, health, aesthetics, etc., is therefore one of key goals in design and construction of new buildings. Unfortunately, the current situation regarding the quality of existing preschool and educational buildings is relatively poor. In fact, buildings in Europe date from different periods with specific building strategies and regulations typical of the time. Approximately $50 \%$ of the existing European building stock dates from the period before 1970 (Eurostat, 2010; Norris \& Shiels, 2004; Poel, Cruchten, \& Balaras, 2007), when building regulations mandating thermal properties of building envelopes were rather loose and inadequate (Konstantinou \& Knaack, 2013). Only after the Energy Performance of Buildings Directive (EPBD) (Directive 2002/91/EC, 2002) came into force, significant efforts to increase the energy efficiency in the operational phase of the building were put forth and became even more pronounced after the implementation of the EPBD recast in 2010 (Directive 2010/31/EU, 2010). The listed data referring to the age of buildings is in accordance with the situation in the field of energy use within which buildings in Europe account for approximately $40 \%$ of the final energy consumption, with the largest share spent on heating. Among non-residential buildings across Europe, the educational buildings represent $17 \%$ with the $12 \%$ share of total energy use (BPIE, 2011). Construction techniques of non-residential buildings, including preschool buildings, are very similar to those of residential buildings, therefore for all building types erected before the introduction of stricter national directives, the refurbishment represents

${ }^{*}$ Corresponding author. E-mail: vesna.zegarac@um.si 
an enormous potential to improve their energy efficiency. A strong argument supporting the need for comprehensive building refurbishment encompassing functional performance and energy efficiency results from a relatively low percentage of the new build, representing only $1 \%$ of the total housing stock in the period from 2005 to 2010 (BPIE, 2011), in fact, the renovation rate is also very low, only around $1.2 \%$ to $2 \%$ per year (European Commission, 2010; Semprini et al., 2016).

In addition, many factors from the economic perspective stimulate investors to support complex building renovation and modernization. Whereby economic evaluation is provided by various project appraisal methods, such as calculations of payback time, net present value $(N P V)$ and internal rate of return $(I R R)$. These approaches are relatively easy to use, but do not cover overall benefits of comprehensive energy efficiency and functional refurbishment projects.

\section{Literature review}

A lot of scientific literature investigates strategies and principles of building renovation. Many studies focus solely on energy efficiency; several include also the aspects of functional renovation, while others deal mainly with the economical viewpoint.

Consideration of different energy retrofit procedures for educational buildings can be found in Semprini et al. (2016), Causone, Carlucci, Moazami, Cattarin, and Lorenzo (2015), Pagliano, Carlucci, Causone, Moazami, and Cattarin (2016), Tahsildoost and Zomorodian (2015), Tanic et al. (2015), Stankovic et al. (2015). Semprini et al. (2016) discusses the energy retrofit measures for the particular educational building in Bologna, where non-invasive interventions with a lower impact had to be considered, since the study treats a case of historical pubic building. Even with limited modifications, the potential for energy saving of 32\% was achieved. Causone et al. (2015) analyze the retrofit measures for the single-storey concrete kindergarten built in Milano in the 1980s. Selection of a comprehensive renovation approach included measures on thermal envelope, lighting, appliances and use of hybrid ventilation strategy, so the primary energy need for building operation was reduced for almost $85 \%$. Moreover, Pagliano et al. (2016) analyse a deep energy renovation of the childcare centre in Milano based on future climate scenarios. The study reveals a serious problem in building design because even the high-performance and zero-energy buildings use current meteorological data files that usually base on 20 year or longer time span average. However, climate patterns are expected to be different in the future, so the analysis identifies that the expected climate change might require far more focus on building cooling strategies. Further, Tahsildoost and Zomorodian (2015) present experimental study of energy refurbishment techniques for two typical school buildings in Tehran. The study introduces a three-step procedure implicating first retrofit measures on building envelope and technical systems, second, optimization of scenarios as a function of energy simulation and simple payback time, and third, assessment of implemented measures. Studies (Tanic et al., 2015; Stankovic et al., 2015) present the possible revitalization principles for preschool buildings in Serbia with a special focus on possibilities for reduction of transmission and ventilation losses in study by Tanic et al. (2015).

Focusing mainly on educational buildings, we can find multiple studies recognizing the impact of indoor climate on productivity of children, or students and teachers (Yun et al., 2014; Mijakowski \& Sowa, 2017; Corgnati, Filippi, \& Viazzo, 2007; Corgnati, Ansaldi, \& Filippi, 2009; Pereira, Raimondo, Corgnati, \& da Silva, 2014; Baker \& Bernstein, 2012). Some of these studies point at an important problem related to energy efficiency renovation measures which are not always in correlation with the development of building indoor climate. Improvement of energy efficiency therefore has to be followed by an adequate control of indoor air quality, thermal, visual and acoustic comfort in order to achieve acceptable living quality conditions.

On the other hand, some research papers consider complex renovation and analyse the impact of renovation measures from perspectives, energy and economic efficiency (Niemelä, Kosonen, \& Jokisalo, 2016; Salvalai, Malighetti, Luchini, \& Girola, 2017; Stocker, Tschurtschenthaler, \& Schrott, 2015; Congedo, D’Agostino, Baglivo, Tornese, \& Zacà, 2016). Studies consider educational buildings built in various construction systems, design typologies and located in different climatic regions. They estimate various scenarios of refurbishment in terms of cost/benefit and use different indicators, most using the NPV. Niemelä et al. (2016) discuss economic viability for energy renovation measures on typical Finnish educational buildings. The results indicate that renovation of building envelope without utilizing renewable energy production systems does not meet the standard of cost-effective retrofit. Salvalai et al. (2017) summarize the result of energy and investment intensity of different renovation measures for two reference school buildings. Investment intensity, given in $€ / \mathrm{kWh}$ per year, shows that the deeper and more expensive renovation measures increase unit costs. Stocker et al. (2015) analyze the efficiency of renovation measures conducted on eight school buildings located in Alps differing in building age. The results show a strong impact of building age and its compactness on NPV and a high effect of investment costs on cost-optimal renovation level. The methodology for the determination of cost-optimal solutions of energy efficient refurbishment was applied also in Congedo et al. (2016) on the case study of two existing educational buildings.

Further research including cost optimal solutions for the renovation of various buildings can be found in Becchio et al. (2016), Bonakdar, Dodoo, and Gustavsson (2014), Pikas, Kurnitskic, Liiasc, and Thalfeldt (2015), Kuusk, Kalamees, Link, Ilomets, and Mikola (2017), Stankevičius, Karbauskaite, Burlingis, Šadauskienè, and Morkvėnas (2014). The economic analyses are mostly performed for concrete and masonry buildings, while the economic analysis of historic timber apartment buildings is discussed in Arumägi and Kalamees (2015), where comparison of the 
effectiveness of different renovation packages is done in terms of investment and energy costs.

The previously presented studies have disclosed few important conclusions, which could serve as starting point for the current study:

- The comprehensive building renovation including measures on thermal envelope and technical systems can lead to the prominent reduction of energy need for building operation;

- The cost-efficiency is not always in correlation with the energy performance, therefore a careful consideration of the economical aspect of building renovation presents a meaningful support to decision makers.

Although treating the issue of complex building refurbishment, the reviewed studies do not integrate a systematic analysis of refurbishment process through the step-by-step evaluation of individual measures from the perspectives of energy and economic efficiency, which presents a valuable scientific contribution of our research. An estimation of individual measures can be beneficial in situations, when investors are obliged to implement steps of renovation gradually due to a lack of financial resources. Therefore, it is highly beneficial to perform analyses in order to determine the optimal solution of the refurbishment strategy in terms of energy performance and costs. In this manner the two-factor method for the assessment of cost efficiency presented in Martinaitis, Kazakevicius, and Vitkauskas (2007) is used also in our study.

Other specifics of the current study are seen in the consideration of refurbishment principles for preschool buildings erected in timber construction system. Finally, an additional contribution of our study lies in the attention being paid to the improvement of building functionality and architectural aesthetic appearance, both factors increasing the building living quality and accounting value.

Despite a high potential to improve the functionality and energy efficiency of educational buildings, many reasons for not implementing such actions prevail more often in practice. Besides the limited financial resources, a strong argument can be found in a lack of knowledge on the systematic renovation concepts. In light of the above mentioned reasons, the objective of the current paper is to present a systematic approach to complex step-by-step renovation based on the case study of preschool building, discussing the aspects of energy efficiency improvement and evaluating cost-effectiveness. Results are evaluated gradually for individual measures and subsequently together for a combination of all the measures. The intensity of measures for the improvement of building functionality is limited in terms of structural requirements of timber construction system and concerning the currently valid national regulations for premises and equipment for kindergartens (Official Gazette of the Republic of Slovenia No. 73, 2010). The regulation based limitations might influence the scope and the cost-efficiency of functional improvements. Finally, the results and conclusions of this study can be drawn for similar building types and construction age in comparable climatic and economic environments. The current research can serve the potential investors in decision-making process referring to the selection of an adequate level of energy and cost efficient renovation in regard to available financial resources.

\section{State of the national educational building stock and in the city of Maribor}

Non-residential buildings represent around $28 \%$ of the Slovenian building stock, while buildings of general social importance represent 9\% (Ministry of Infrastructure \& Ministry of Public Administration, 2015). Currently, altogether 1163 kindergartens are organized in buildings entirely or partly used for pre-school educational purposes (Ministry of Education, Science and Sport, 2018). The many of these buildings are designed in the single-panel timber-frame structural system according to data from the regions of Slovenia and former Yugoslav countries, revealing that 360 pre-educational building were erected in this manner in 60s, 70s and 80s (Žegarac Leskovar, Premrov, \& Kitek Kuzman, 2012). At that time, and especially until 1980, the minimal national requirements for thermal performance of building envelopes were rather poor with the prescribed $U$ values around $U=1.28-1.68 \mathrm{~W} /\left(\mathrm{m}^{2} \mathrm{~K}\right)$ (Official Gazette of the Socialist Federal Republic of Yugoslavia No. 35, 1970). The aforementioned data indicates a relatively high potential for building energy retrofit, which begun to be implemented more intensively after the adoption of the EPBD (European Commission, 2010) and with a support of financial instruments of EU funds. As a result, 251 educational buildings in Slovenia were subject to energy renovations (partial or complete), among them 65 preschool (Ministry of Infrastructure, 2018). In this research, further analyses relate to preschool buildings.

A representative sample of kindergartens located in the city of Maribor is chosen to describe the building stock situation of preschool buildings in Slovenia. Altogether there are 35 preschool buildings in Maribor, with total net floor area of $26310 \mathrm{~m}^{2}$ (Ministry of the Environment and Spatial Planning, 2018). From Figure 1 it is evident that most of them were built in the period from 1950 to 1990, whereas from 1971 to 1980 they were mostly built in timber-frame panel structural system.

So far, only five buildings have been completely energy renovated, while partial renovations were carried

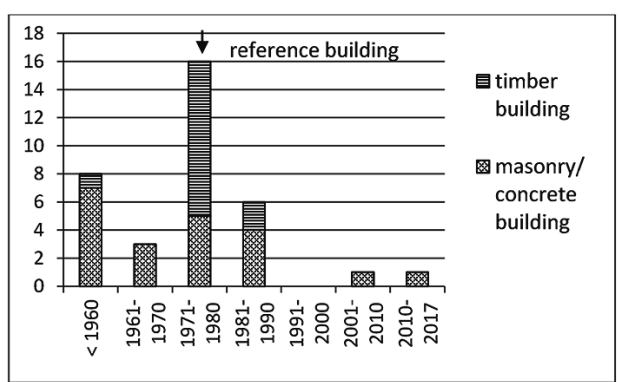

Figure 1. State of the preschool buildings in the city of Maribor by the year of construction and type of structural system (Ministry of the Environment and Spatial Planning, 2018) 
out in 28 buildings and, 21 of which after 2010, and 9 of them were subject to renovation of heating system. The implementation of complex renovations (thermal envelope and installation of heat recovery ventilation systems) accounted for about $340 € / \mathrm{m}^{2}$ to $470 € / \mathrm{m}^{2}$ (net floor area), while for building with small usable area is about $970 € / \mathrm{m}^{2}$ (City Municipality Maribor, 2018). In summary, most of the preschool building stock in Slovenia remains energy inefficient.

\section{Introduction to systematic integrated building renovation process}

The complex refurbishment process consists of individual renovation actions, resulting in refurbishment strategy of the building. It is important that already in early design stage the design strategy planning is approached systematically. Typically, refurbishment of preschool buildings is designed by using various strategies, from the basic thermal update of thermal envelope to more sophisticated solutions, within adding of extra space and other functional improvements.

Consequently, systematic integrated approach would be reasonable for supporting the evaluation of individual renovation action. Approach proposes an analysis of energy savings and economic benefits of single measures as specified in refurbishment strategy. In the first phase, systematic compilation of different measures and their organization in terms of energy and functional improvement should be introduced. This is followed by a selection of the refurbishment strategy and precise definition of step-bystep measures. The next approach phase evaluates the way how proposed measures contribute to energy and economic efficiency. First, investment costs are determined, then the effects of energy savings measures and benefits for all measures are evaluated.

\subsection{Reduction of energy flows in buildings by energy renovation process}

Energy efficiency of the building means the amount of energy required for its usual operation, including the heating $\left(Q_{h}\right)$, cooling $(Q c)$ and ventilation demands $\left(Q_{v}\right)$ in addition to hot water supply and lighting energy consumption. The energy balance of the building generally consists of the transmission heat losses $\left(Q_{t}\right)$, ventilation heat losses $\left(Q_{\nu}\right)$, internal heat gains $\left(Q_{i}\right)$ and solar heat gains $\left(Q_{s}\right)$, given in the form of Eqn (1). Based on different temperatures of the building and its surroundings we can distinguish between two opposite heat flow scenarios.

In a heating period of the year when the average outdoor temperature is generally lower than the prescribed indoor temperature, the sum of all heat flows in the building is usually negative, which is mainly due to the energy output caused by transmission and ventilation heat losses. In such cases the $\Delta Q$ results in the amount of energy required for heating $\left(Q_{h}\right)$ in order to reach a desired indoor temperature of approximately $20^{\circ} \mathrm{C}$, Eqn (1), in the form of:

$$
\begin{aligned}
Q_{t}+Q_{v}+\left(Q_{i}+Q_{s}\right)=\Delta Q & =Q_{h} \ldots \text { in heating period; } \\
& =Q_{c} \ldots \text { in cooling period }
\end{aligned}
$$

Renovation phase a: Renovation of thermal envelope elements by adding the thermal insulation

This is the most popular approach in the building renovation process. By adding thermal insulation on the external (or internal) side of the envelope elements, the thermal transmittance (U-value) decreases and consequently results in reduction of the transmission losses $\left(Q_{t}\right)$. It is usually also the technologically easiest and one of the cheapest approaches in building renovation.

Renovation phase b: Replacement of windows by the new type of glazing with reduced $U$-value and possible increasing of the glazing areas on the south façades

This phase is also one of the most popular approaches in which is many times performed as a single (and the only) renovation phase. In this approach, the old existing windows are replaced by the new type of glazing with essentially lower thermal transmittance $\left(U_{w} Q_{h}\right)$, so the transmission losses through the windows can be essentially decreased. However, it is highly recommended to combine the phase 1 and 2 .

Moreover, the glazing areas on the south façades can be increased, which is a quite new approach in energy renovation of old buildings. Respecting the fact that dynamic evolution of the glazing in the last decades has resulted in insulating glass products with highly improved physical properties, especially the decreased U-value, and that the g-value does not decrease in the same way (see subsection 4.2.1, RP 2), the solar gains $\left(Q_{s}\right)$ through the glazing can be larger than the transmission losses $\left(Q_{t}\right)$ through the same glazing area, especially on the south side of the building envelope. Respecting Eqn (1) it is obvious that the heat demand $\left(Q_{h}\right)$ can even decrease in this case, but on the other hand, the cooling demand $\left(Q_{c}\right)$ can increase in the summer period. However, we should be very carefully with this implementation. Several parametric numerical studies about this fact are presented in Žegarac Leskovar and Premrov $(2011,2013)$, Premrov, Žigart, and Žegarac Leskovar (2018).

\section{Renovation phase c: Vertical building extension with lightweight upgrade module}

Furthermore, reduction of transmission losses can be introduced by constructing the upgrade module on the top of the existing building. A difference between previously performed renovation possibilities and the proposed one lies in the change of energy flows as the "bottom plate" of the upgrade module becomes a building element between two heated rooms. The optimal upgrade module shape depends on several changeable parameters such as the module shape, the proportion of glazing in the southoriented façade, in addition to the thermal transmittance of the external walls and the roof. The study of Špegelj, Žegarac Leskovar, and Premrov (2016) shows a positive impact of building extension by the upgrade module with the optimal glazing size in south-oriented façade on energy savings. Implementation of the previously especially developed timber-glass upgrade module with enlarged glaz- 
ing size on the south façade is studied in Premrov, Žigart, and Žegarac Leskovar (2017).

\section{Renovation phase d: Installation of heat recovery} air-exchange systems to reduce ventilation losses

Ventilation heat losses $\left(Q_{v}\right)$ are usually reduced by improvement of the building airtightness and by insertion of the system of the air exchange (heat recovery). However, technologically this is usually not an easy approach at all, but it can reduce the ventilation losses in average for 4 to 8 times.

\subsection{Methods for economic evaluations}

At present, there are several economic analysis methods for quantifying benefits of the building complex renovation e.g. simple payback period (SPP), NPV, IRR, and cost of conserved energy (CCE). Among these the CCE is the most readily and comprehensible criterion for noneconomists which stipulates that investment in a measure is economically efficient if CCE is lower than the average cost of primary energy in the useful time of the measure (Petersen \& Svendsen, 2012). The basic indicator of CCE is defined as (Martinaitis, Rogoža, \&d Bikmanien, 2004):

$$
C C E=\frac{I_{\text {measure }} \cdot C R F}{d E_{\text {year }}},
$$

where $I_{\text {measure }}$ is the investment cost, $C R F$ is the capital recovery factor, and $d E_{\text {year }}$ is the annual energy saving by the measure (e.g. kWh). CRF includes annual discount rate $(r)$ and for the benefits of energy efficiency investments, rates are between $2 \%$ and $4 \%$ (Bonakdar et al., 2014; Pikas et al., 2015). Recently, the CCE concept has been used in assessment of economic efficiency for new building (Petersen \& Svendsen, 2012) and for renovation (Martinaitis et al., 2004, 2007).

However, applied methods in most cases consider only the reduction of heating costs as sole benefits of energy saving project while other benefits such as improvement of building elements condition, extension of durability and increasing value of the building is neglected. In capturing all benefits of complex improvement project, a two-factor evaluation method should be used (Martinaitis et al., 2007).

In order to analyze real example of complex building renovation by using a two-factor evaluation method, it is necessary to introduce indexes. The summery for the case study is: $E$ related to the pure energy efficiency measures; $A$ associated with the measures of adding lightweight upgrade module; $F$ addressed to functional improvement measures including structural building improvements and renovation measures; and $T$ related to the so-called "two-fold" measures. The "two-fold" measure includes both benefits from energy savings and improvement of building elements. The economic analysis is made by using the following steps:

Step 1: Calculation of total investment costs

Total investment cost $\left(\sum I_{\text {TAEF }}\right)$ is the amount of all types of measures, including construction, finishing and installation works, and can be calculated:

$$
\sum I_{T A E F}=\sum I_{T}+\sum I_{A}+\sum I_{E}+\sum I_{F},
$$

where $I_{T}$ is the amount of investment of two-fold measures; $I_{A}$ the amount of investment for adding module measure; $I_{E}$ the amount of investment of energy efficiency measures; and $I_{F}$ the amount of investment of functional measures.

Step 2: Grouping of investments using two-factor method

Initially, each of the investments can be classified as homogeneous measures (include $I_{E}, I_{F}$ and $I_{A}$ ), or as those related to the two-fold measures $\left(I_{T}\right)$. The latter can be further subdivided into the energy saving $\left(I_{T E}\right)$ and the building renovation and improvement $\left(I_{T F}\right)$ component. Next, investments are separated into two groups; a) energy saving measures $\left(I_{T E E}\right)$, and b) functional improvement measures and adding lightweight module $\left(I_{\text {TFAF }}\right)$.

Step 3: Evaluation of cost effectiveness of individual investments measure divided into groups

a) Investments in $I_{T E E}$ include two components $I_{E}$ and $I_{T E}$ and are evaluated using $S P P$ and $C C E$. The $S P P$ is ratio between initial investment cost of measure, and annual costs for conserved energy evaluated at year 0 . The disadvantage of this criterion is neglect of lifespan of an energy saving measure. This aspect is reflected in the CCE criterion. The basic definition of CCE is used (Eqn (2)) for homogeneous energy saving measure $\left(I_{E}\right)$ and the modified formula of $C C E_{T}$ is introduced for energy saving of two-fold measures $\left(I_{T E}\right)$ by using building rehabilitation coefficient $\kappa$ :

$$
C C E_{T}=\frac{(1-\kappa) \cdot I_{\text {measure }} \cdot C R F}{d E_{\text {year }}},
$$

where $\kappa$ represents the ratio between the lifespan of building element (in years) and the actual age of an element (in years). In our case study, the linear function for physical deterioration of the building's element condition is applied, while lifespan is summarized by Rules (Official Gazette of the Republic of Slovenia No. 20, 2004).

b) Investments in $I_{T F A F}$ contain three components $I_{T F}$, $I_{A}$ and $I_{F}$. Benefits of those measures should be expressed with the social and environment effects e.g. indoor living quality (air quality, thermal, visual and acoustic comfort), aesthetics, reduced $\mathrm{CO}_{2}$ emissions and others. In addition, the measure of new module increases the total net floor area and has direct effect on satisfying the requirements of the modern standards for kindergartens (Official Gazette of the Republic of Slovenia No. 73, 2010) as well as on increasing the value of the property. For these measures, certain standard evaluation methods could be used. Their appraising needs sophisticated tools and includes analysis with large number of criteria, thus such methods are not covered in the scope of this paper. Anyhow, our case study uses the model of valuation of tangible fixed assets according to accounting standards (Official Gazette of the Republic of Slovenia No. 95, 2015), namely increase of the purchase value of fixed assets. The increased value represents investment for $I_{T F}, I_{A}$ and $I_{F}$ by using coefficient $\kappa$. 


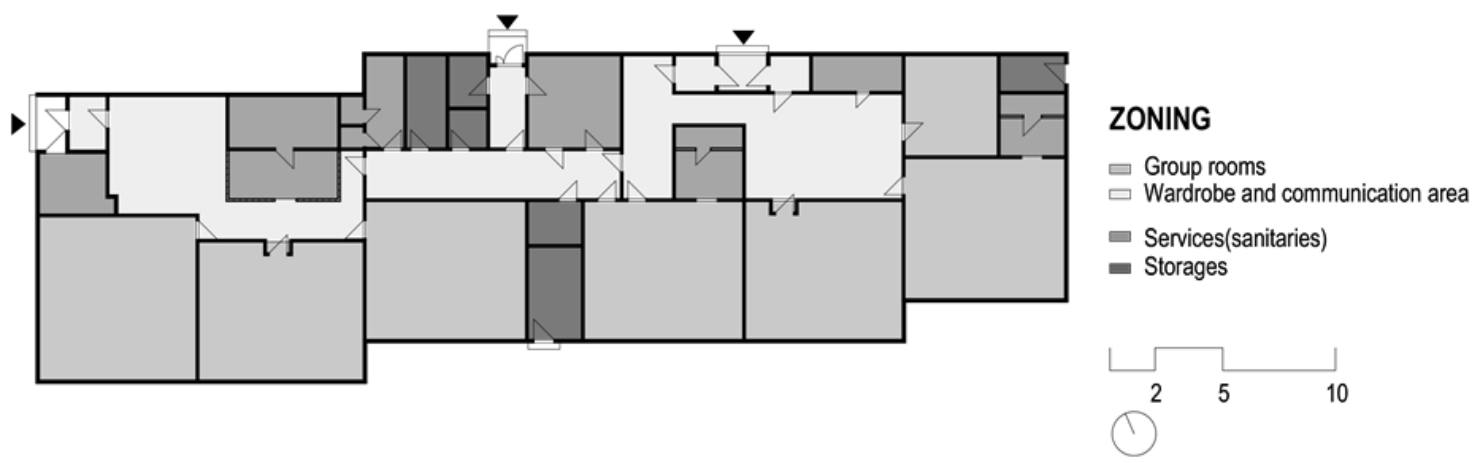

Figure 2. Ground floor plan of Kindergarten Mojca (adapted from Ivačič, Jashanica, Lešnik, \& Stopar, 2014)

\section{Case study}

The study focuses on the complex renovation of typical Slovenian preschool building built in 1970s. The modernization approach requires functional adaptations alongside with energy efficient measures in order to reduce energy consumption and to establish an adequate indoor living climate for children and staff.

\subsection{Description of the existing building}

The research is based on the case study of Kindergarten Pobrežje, Unit Mojca (hereinafter referred as Kindergarten Mojca) presenting the typical preschool building type built widely in 1970s and 1980s in Slovenia and also in the other areas of former Yugoslavia. The Kindergarten Mojca was built in Maribor in the year 1978 and until now the building has not been renovated; only the basic maintenance works were carried out. It is built in a single-panel timber-frame structural system and has north-south orientation with service, storage, communication areas and wardrobes mostly oriented to the north and group rooms oriented to the south (Figure 2).

According to its physical condition (Figure 3), the building requires deep renovation alongside the need to increase the usable floor area and the standard of living comfort. The playrooms on the south side of the building suffer from overheating in summer due to light timber construction with thin insulation layer in combination with large south-oriented old wooden windows with inefficient shading. In winter, the building has high infiltration air rates, and the natural ventilation is not adequate in cer- tain times of the day. The layout of the rooms is organized properly according to orientation, but it lacks functional spaces, such as multipurpose room, gym, play areas, offices for preschool teachers, space for medical treatment, terraces, etc.

\subsubsection{Calculation methods and software}

The software Passive House Planning Package - PHPP 8 (Feist, 2013) is used for the calculation of the energy balance of individual refurbishments phases. Results are energy performance indicators including energy need for heating $Q_{h}$ and cooling $Q_{c}$. Based on detailed data on implemented renovation measures and associated results for energy balance, each renovation phase is economically assessed. A two-factor evaluation method is used. The cost effectiveness is evaluated with indicators SPP and CCE for energy saving measures, while the method of increasing value of the building is used for functional measures.

\subsubsection{Climate data}

The building is located in the city of Maribor. The average annual temperature is $10.7^{\circ} \mathrm{C}$ with the lowest average temperature in January of $-0.8^{\circ} \mathrm{C}$ and the highest average temperature in July being $+20.8^{\circ} \mathrm{C}$. The average daily temperature range in summer is recorded to be $\pm 10.9^{\circ} \mathrm{C}$. The average length of the heating season is 187 days. The average horizontal solar radiation is $1225 \mathrm{kWh} /\left(\mathrm{m}^{2} \mathrm{a}\right)$ (Meteonorm Software, 2018). The average number of solar hours in the period from 1981 and 2010 is approximately 2000-2050 annually (Environmental Agency of the Republic of Slovenia, 2018).
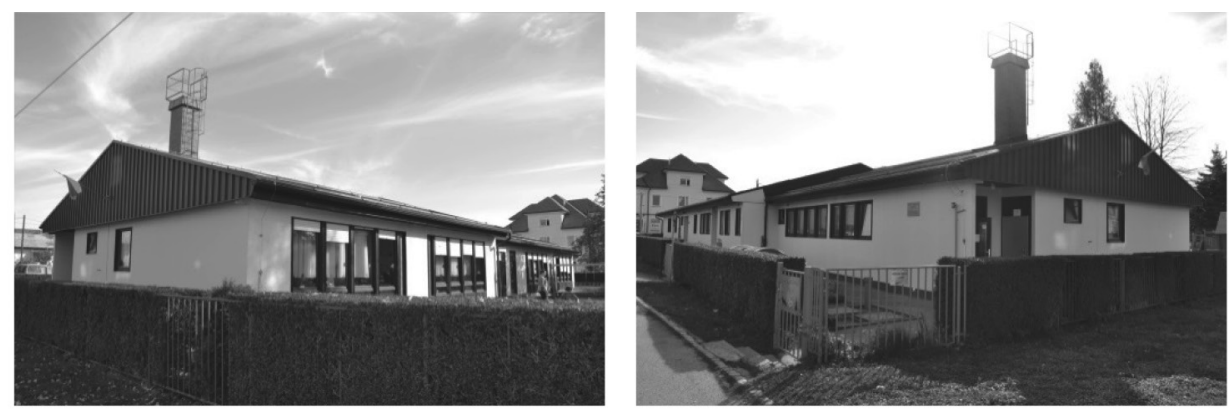

Figure 3. South (left) and north (right) façade view of Kindergarten Mojca Maribor (2014) 


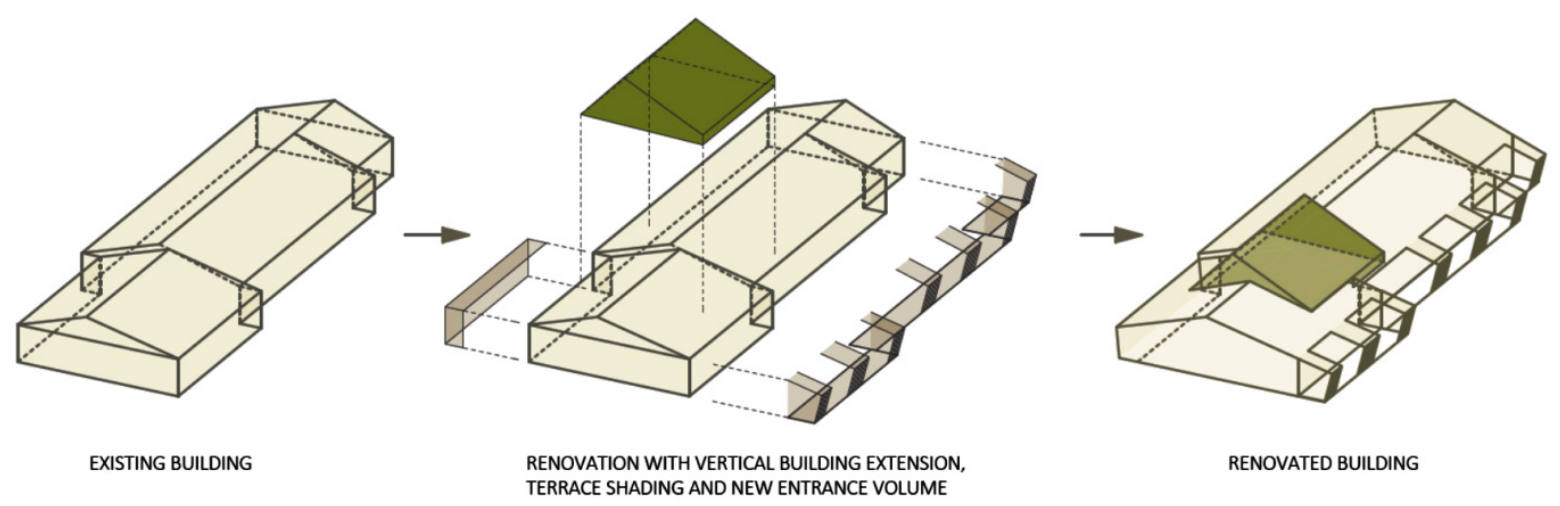

Figure 4. The scheme of the renovation concept (Ivačič et al., 2014)

\subsubsection{Default indoor conditions}

Thermal comfort conditions are set by the minimum interior temperature of $22^{\circ} \mathrm{C}$ during the heating period and $25^{\circ} \mathrm{C}$ during the warm weather period. The internal gains in value of $2.80 \mathrm{~W} / \mathrm{m}^{2}$ are determined by PHPP software. Infiltration air change rate at pressure difference of $50 \mathrm{~Pa}$ prior to renovation is assumed to be $5 \mathrm{~h}^{-1}$. The assumption is based on the analysis of similar buildings (Norris \& Shiels, 2004). The natural ventilation with average air change rate $(n)$ of $0.5 \mathrm{~h}^{-1}$ is selected.

\subsection{Renovation concept}

As the kindergarten usable floor area no longer suffices today's needs, the main functional requirement is to extend the building. Since the scale of horizontal extension of the building is limited, the vertical extension with the upgrade module (Figure 4) is selected and to obtain additional spaces for employees. Another architectural intervention such as addition of new entrance volume on the north and covered terraces on the south are carried out (Figure 4). Moreover, the terraces act as shading elements for the southern facing windows.

Also an important aim of the renovation is related to the energy savings measures resulting from improvement of building envelope (described in 4.2.1). The implementation of the above mentioned measures enable the positive impact on the indoor building climate. Apart from the improvement of structural building elements, the modernization of active technical systems is implemented as well. The old system with heating generator on oil is substituted by the heat pump, while the central heat recovery ventilation system is installed for the ventilation. However, the improvement of interior electrical installation and artificial lighting is not treated in this paper.

\subsubsection{Description of implemented measures for complex renovation}

Complex renovation of includes measures contributing to energy and functional improvements and is divided into ten consecutive renovation phases (RP), described in detail below.
RP 1: Renovation of the thermal envelope components

RP 1.1: Renovation of floor plate

Removal of existing layers: flooring, cement screed, PE foil, thermal insulation (polystyrene) $-2 \mathrm{~cm}$;

Replacement with new layers: flooring, cement screed, PE foil, thermal insulation (aerogel) $+4 \mathrm{~cm}$.

RP 1.2: Renovation of external walls

Removal of existing layers: corrugated asbestos-cement panels;

Replacement with new layers: gypsum fibre boards, thermal insulation $+15 \mathrm{~cm}$, final plaster.

RP 1.3: Renovation of ceiling

Addition of new layers: thermal insulation $+12 \mathrm{~cm}$;

Removal of roof and ceiling structure in the area of module upgrade.

RP 2: Replacement of glazing

Removal of existing windows: $g=77 \%, U_{g}=2.3 \mathrm{~W} /\left(\mathrm{m}^{2} \mathrm{~K}\right)$, $U_{f}=1.6 \mathrm{~W} /\left(\mathrm{m}^{2} \mathrm{~K}\right), \psi_{\text {spacer }}=0.04 \mathrm{~W} /(\mathrm{mK})$;

Installation of new windows: $g=50 \%, U_{g}=0.64 \mathrm{~W} /\left(\mathrm{m}^{2} \mathrm{~K}\right)$, $U_{f}=0.72 \mathrm{~W} /\left(\mathrm{m}^{2} \mathrm{~K}\right), \psi_{\text {spacer }}=0.035 \mathrm{~W} /(\mathrm{mK})$.

RP 3: Terrace shading

Installation of timber roof structure over the terraces; Installation of blinds with support structure made of aluminium profiles.

RP 4: Building extension with lightweight upgrade module Prefabricated timber-frame macro-panel structural system;

Additional $130 \mathrm{~m}^{2}$ of treated floor area and $392 \mathrm{~m}^{3}$ of volume in the 1st floor;

Extension with: walls $U=0.153 \mathrm{~W} /\left(\mathrm{m}^{2} \mathrm{~K}\right)$, roof $U=0.136 \mathrm{~W} /\left(\mathrm{m}^{2} \mathrm{~K}\right)$, roof windows: $g=53 \%, U_{g}=$ $0.50 \mathrm{~W} /\left(\mathrm{m}^{2} \mathrm{~K}\right), U_{f}=1.6 \mathrm{~W} /\left(\mathrm{m}^{2} \mathrm{~K}\right), \psi_{\text {spacer }}=0.04 \mathrm{~W} /(\mathrm{mK})$, skylights: $g=77 \%, U_{g}=2.4 \mathrm{~W} /\left(\mathrm{m}^{2} \mathrm{~K}\right), U_{f}=1.6 \mathrm{~W} /\left(\mathrm{m}^{2} \mathrm{~K}\right)$, $\psi_{\text {spacer }}=0.04 \mathrm{~W} /(\mathrm{mK})$.

Airtightness is gradually improved through individual renovation measures to the final value of $1.5 \mathrm{~h}^{-1}$, which is fairly under the maximum limit $\left(2 \mathrm{~h}^{-1}\right.$ for energy-efficient buildings with mechanical ventilation) prescribed in the national technical guidelines (Ministry of the Environment and Spatial Planning, 2010). 
RP 5: Installation of the heat-recovery ventilation system Central ventilation unit within the thermal envelope with effective heat recovery efficiency of $84 \%$ and average air change rate $(\mathrm{n})$ of $0.5 \mathrm{~h}^{-1}$.

RP 6 to 10: Functional improvement measures

Replacement of roofing and internal doors, new internal walls and entrances, supporting structure for shading terraces, and renovation of heating system.

The renovation measures of floor plate (RP 1.1.) were limited to the thinnest possible insulation in order to preserve the prescribed clear ceiling height of playrooms (Official Gazette of the Republic of Slovenia No. 73, 2010). The measure of adding terraces is divided into energy improvement, including the building of new structure and adding blinds for shading (in RP 3), and into functional improvement, including the renovation of wood pavement. The measure to increase the glazing areas is not carried out because the building already has suitable glazing on the south façade. Table 1 gives a description of technical and geometrical properties of the building. The input data is based on the existing technical drawings and plans and the $U$-values are calculated according to the assembly of the thermal envelope.

\subsection{Results of the complex renovation}

In order to follow results easier, they are separated. First, the results of energy efficiency analysis are described in steps. Then, the cost data are added and economic analysis is provided.

\subsubsection{Results for energy efficiency}

The energy efficiency analysis is made for RPs $1-5$. The overall treated floor area of Kindergarten Mojca accounts for $522.46 \mathrm{~m}^{2}$. In Table 2 we can see that energy need for heating prior to renovation is $148.9 \mathrm{kWh} /\left(\mathrm{m}^{2} \mathrm{a}\right)$, while energy need for cooling accounts for $9.3 \mathrm{ckWh} /\left(\mathrm{m}^{2} \mathrm{a}\right)$. The
$U$-values (Table 1 ) of the thermal envelope are calculated on the basis of individual element composition, whereby the long term deterioration of the material's thermal conductivity is not taken into account.

Table 2 presents the state of energy flows and energy demand after the implementation of individual RPs. The values of energy indicators are given on annual basis in two columns, firstly normed per square meter of usable floor area and secondly as an absolute value, and are calculated using Eqn (1).

The results presented in Table 2 show the influence that certain RPs exert on energy demand reduction. The strongest influence on the reduction of transmission losses is achieved by RP1- renovation of the building thermal envelope components $\left(\Delta Q_{t}=-54.5 \mathrm{kWh} /\left(\mathrm{m}^{2} \mathrm{a}\right)\right)$. Further observation shows that the renovation of $1 \mathrm{~m}^{2}$ of external wall causes the reduction of $Q_{t}$ for $33.07 \mathrm{kWh} / \mathrm{a}$, reduction of $Q_{t}$ caused by the renovation of $1 \mathrm{~m}^{2}$ of ceiling is $19.18 \mathrm{kWh}$, while for $1 \mathrm{~m}^{2}$ of floor plate the $Q_{t}$ saving accounts only $13.28 \mathrm{kWh} / \mathrm{a}$. On the other hand, the influence of the building extension with lightweight upgrade module (RP 4) on transmission losses is lower, which is rather expected due to an overall increase of thermal envelope surfaces, even though the roof of existing building is not covered in total by the upgrade module. Ventilation losses $\left(Q_{v}\right)$ mostly depend on the system of the air exchange (RP 5), but there is also an important decrease evident by RP 1 and glazing replacement (RP 2) due to the improved air-tightness. The internal gains $\left(Q_{i}\right)$ remain constant throughout all renovation phases. The solar gains $\left(Q_{s}\right)$ are almost constant for all considered RP 1 phases, whilst a higher decrease is caused by RP 2 on account of lower g-value of newly installed 3-pane windows. The installation of the timber-glass upgrade module (RP 4) with glazing designed predominately on the south façade significantly increases the solar gains $\left(\Delta Q_{s}=+3.80 \mathrm{kWh} /\left(\mathrm{m}^{2} \mathrm{a}\right)\right)$ and has a positive impact on total energy demand in the building.

Table 1. Technical and geometrical properties of the Kindergarten Mojca

\begin{tabular}{|l|l|l|r|r|}
\hline \multirow{2}{*}{\multicolumn{1}{c|}{ Building }} & \multicolumn{2}{c|}{ Before renovation } & \multicolumn{2}{c|}{ After renovation } \\
\cline { 2 - 5 } & \multicolumn{1}{c|}{$\begin{array}{c}A_{\text {net }} \\
{\left[\mathrm{m}^{2}\right]}\end{array}$} & $\begin{array}{c}\text { Average } \\
U \text {-value } \\
{\left[\mathrm{W} /\left(\mathrm{m}^{2} \mathrm{~K}\right)\right]}\end{array}$ & $\begin{array}{c}A_{\text {net }} \\
{\left[\mathrm{m}^{2}\right]}\end{array}$ & $\begin{array}{c}\text { Average } \\
U \text {-value } \\
{\left[\mathrm{W} /\left(\mathrm{m}^{2} \mathrm{~K}\right)\right]}\end{array}$ \\
\hline treated floor area & 522.46 & & 652.46 & \\
north façade windows & 30.81 & $2.30 / 1.60^{*}$ & 28.30 & $0.64 / 0.72^{*}$ \\
east façade windows & 2.07 & $2.30 / 1.60^{*}$ & 2.07 & $0.64 / 0.72^{*}$ \\
south façade windows & 66.15 & $2.30 / 1.60^{*}$ & 66.15 & $0.64 / 0.72^{*}$ \\
west façade windows & 3.36 & $2.30 / 1.60^{*}$ & 5.31 & $0.64 / 0.72^{*}$ \\
horizontal windows & 0.00 & $/$ & 29.54 & $0.64 / 0.72^{*}$ \\
exterior door & 16.83 & 1.07 & 16.83 & 1.07 \\
exterior wall & 296.8 & 0.59 & 296.80 & 0.17 \\
exterior wall of new module & $/$ & $/$ & 90.00 & 0.15 \\
ceiling & 575.9 & 0.42 & 570.00 & 0.17 \\
floor slab & 575.9 & 0.18 & 575.90 & 0.28 \\
total thermal envelope & 1567.82 & & 1681.00 & \\
\hline
\end{tabular}

Note: ${ }^{*} U_{\text {glass }} / U_{\text {frame }}$. 


\begin{tabular}{|c|c|c|c|c|c|c|c|c|c|c|}
\hline 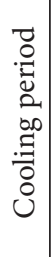 & 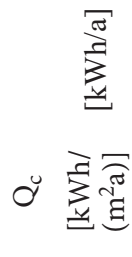 & $a$ & & $\begin{array}{l}\infty \\
0 \\
i \\
+ \\
0 \\
\infty \\
\infty\end{array}$ & $\stackrel{\circ}{\stackrel{\circ}{\circ}}$ & $\underset{m}{\stackrel{ }{m}}$ & $\begin{array}{l}\text { Ĩ } \\
\text { cे }\end{array}$ & $\begin{array}{l}\stackrel{\infty}{0} \\
= \\
\vec{i}\end{array}$ & $\begin{array}{l}\stackrel{ }{\subseteq} \\
\stackrel{i}{\wedge}\end{array}$ & $\begin{array}{l}\stackrel{\infty}{n} \\
\stackrel{n}{i}\end{array}$ \\
\hline \multirow{5}{*}{ 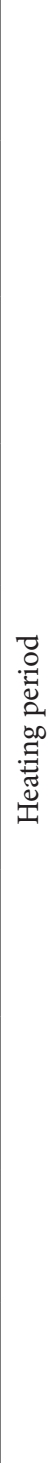 } & 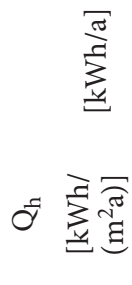 & 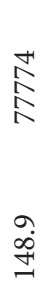 & & 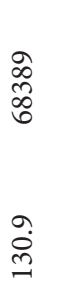 & $\begin{array}{l}\vec{n} \\
0 \\
i \\
i \\
+1 \\
\infty \\
0\end{array}$ & $\underset{\tilde{N}}{\tilde{F}}$ & 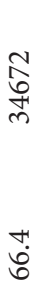 & $\begin{array}{l}\text { Na } \\
\text { bे } \\
\text { H' }\end{array}$ & 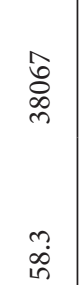 & $\begin{array}{l}\infty^{+} \\
\infty \\
\sim \\
\end{array}$ \\
\hline & 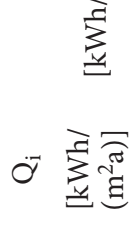 & 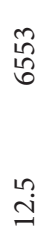 & & 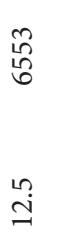 & 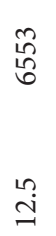 & 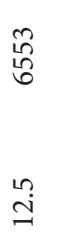 & 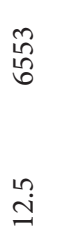 & $\begin{array}{l}\hat{\bigcap} \\
\hat{6} \\
0 \\
\\
\end{array}$ & $\begin{array}{l}\infty \\
\infty \\
\infty \\
10 \\
\stackrel{1}{]}\end{array}$ & $\begin{array}{l}\stackrel{+}{\infty} \\
\infty \\
\stackrel{n}{]}\end{array}$ \\
\hline & 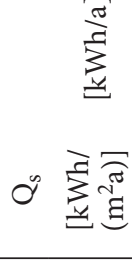 & 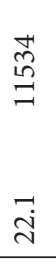 & & $\begin{array}{l}\stackrel{\vec{N}}{\stackrel{\Omega}{Z}} \\
\vec{i} \\
\vec{i}\end{array}$ & 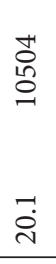 & 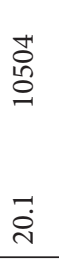 & $\begin{array}{l}\overrightarrow{0} \\
\dot{0} \\
\overrightarrow{0} \\
\vec{\Rightarrow}\end{array}$ & $\begin{array}{l}\overrightarrow{0} \\
0 \\
\overrightarrow{0} \\
\vec{D}\end{array}$ & 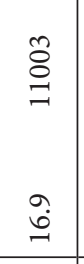 & $\begin{array}{l}\stackrel{0}{0} \\
= \\
\dot{\sigma} \\
\stackrel{-}{\sigma}\end{array}$ \\
\hline & 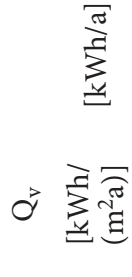 & 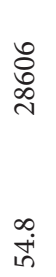 & & 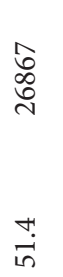 & 을 & $\begin{array}{l}\underset{\sim}{\infty} \\
\underset{\sim}{\sim}\end{array}$ & $\begin{array}{l}\text { ڤे } \\
\text { ठे } \\
\text { लें }\end{array}$ & $\begin{array}{l}\hat{\text { ڤे }} \\
\text { } \\
\ddot{\dot{m}}\end{array}$ & 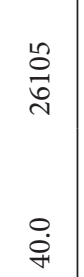 & $\begin{array}{l}\stackrel{\infty}{\circ} \\
\stackrel{ }{=} \\
\stackrel{\infty}{=}\end{array}$ \\
\hline & 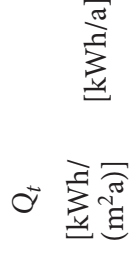 & 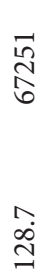 & & $\begin{array}{l}\text { 今े } \\
\text { iे }\end{array}$ & $\begin{array}{l}\stackrel{\infty}{ } \\
\stackrel{\circ}{\sigma}\end{array}$ & 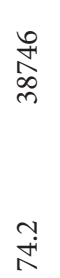 & 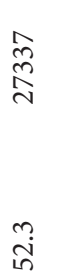 & $\stackrel{\hat{N}}{\hat{N}}$ & 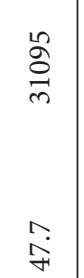 & $\begin{array}{l}\frac{n}{0} \\
\frac{0}{n}\end{array}$ \\
\hline & 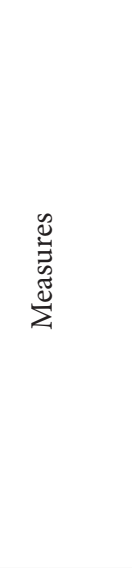 & 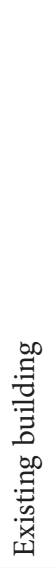 & 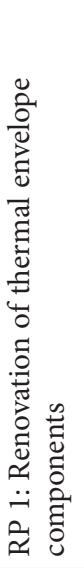 & 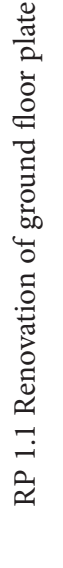 & 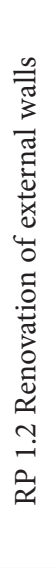 & 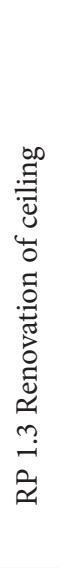 & 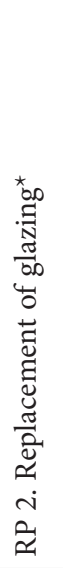 & 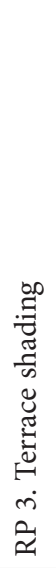 & 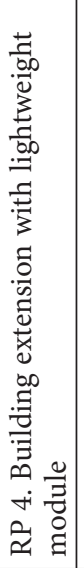 & 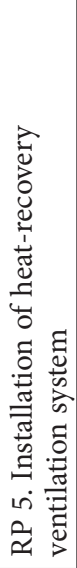 \\
\hline
\end{tabular}


The analyzed energy flows' behaviour correlates to the reduction of energy demand for heating $\left(Q_{h}\right)$. Comparison of phases shows relatively great reduction of $Q_{h}$ caused by the renovation measures on external envelope, by replacement of glazing, and with the installation of a heat recovery ventilation system. The influence of the upgrade module installation (RP 4) on $Q_{h}$ decrease is slightly smaller. However, this particular RP helps to obtain the additional necessary usable floor area resulting in an essentially increased financial value of such renovated building.

In fact, the summer period in Maribor is relatively warm and the approximate number of solar hours is high, therefore, the energy need for cooling $\left(Q_{c}\right)$ should be taken into account as well as the control of the overheating risk. The results for $Q_{c}$ listed in Table 2 show an important influence of energy decrease for cooling caused by all the considered renovation phases and the values with the highest contribution of terrace shading.

Finally, taking into consideration the sum of heating and cooling energy needs as the total annual energy need $\left(Q_{h}+Q_{c}\right)$ is important for the buildings located in the moderate climate with cold winters and warm summers.

\subsubsection{Results for economic efficiency}

Economic analysis is carried out for all RP of complex renovation. The present average heat price is $106 € / \mathrm{MWh}$. Investment costs for the renovation works are set on the prices obtained from the companies in the Slovenian market and include VAT. In addition, different lifespans (in years) are applied for individual building element summarized from Rules (Official Gazette of the Republic of Slovenia No. 20, 2004), representing the basis for the calculation of the coefficient $\kappa$.

Calculation of the CCE indicator is performed using $r=4 \%$. However, the problem of accurate prediction of growth rate and expected time of evaluation remains when this value should be determined. The factor namely considers the return on investment in the lifespan of the building, which can differ from the expected profitability, increasing the investment risk and consequently changing the value of $r$.

According to two-factor evaluation method, all RPs are divided in two groups $I_{T E E}$ and $I_{\text {TFAF }}$ (see Table 3). Measures related to $I_{T E E}$ are considered in RPs 1-3 and RP 5. First two phases are related to $I_{T}$ elements (divided in $I_{T E}$ and $I_{T F}$ ) and include the total cost for all new added layers, while RP 3 refers to measure of cooling, and the value represents costs for energy savings because the element is new. Next, RP 5 represents homogeneous energy savings measure $I_{E}$. Further, measures related to $I_{T F A F}$ are considered partly in PR1 and RP as $I_{T F}$, in RP 4 as homogeneous measure of building extension $I_{A}$, and in RPs 6-10 as investments related to measures of functional improvements $I_{F}$. Table 3 presents the main results of economic analysis. Eqn (3) is used for the total amount of the investment. The indicator CCE is given for homogenous energy saving measures $I_{E}$ (Eqn (2)) and for $I_{T E}$ the modified indicator $C C E_{T}$ is employed by using Eqn (4). For measures which do not affect the energy efficiency the calculations of indicators are not applicable (N/a).

Total amount of investment $\left(\sum I_{T A E F}\right)$ is $1002.11 € / \mathrm{m}^{2}$ (Eqn (3)), where almost 45\% accounts for energy renovation measures $\left(I_{T}\right.$ and $\left.I_{E}\right)$, which is comparable to the costs of complex energy renovations of kindergartens (City municipality Maribor, 2018). Furthermore, demolition works constitute $4.5 \%$ of all costs.

a) Economic indicators for energy saving measures

Economic indicators for energy saving measures in Table 3 are given separately and also joined together. Considering measures separately, without regarding two-fold benefits, the economic indicators are unfavorable for almost all measures, because costs of demolition of the existing layers and the implementation of finishing layers are included. In that, a RP 1.1 and RP 5 are significantly cost ineffective, and together represent of $28.1 \%$.

After grouping of investments together, i.e. components of two-fold measures $\left(I_{T E}\right)$ and a homogenous energy saving measures $\left(I_{E}\right)$, the results show that investment is sensible. Total investment in energy saving measures $\left(I_{T E E}\right)$ is equal to $199.7 € / \mathrm{m}^{2}$, and economic indicators are favorable, namely CCE (Eqn (4)) is $96.9 € / \mathrm{MWh}$, and lower than the current heating price, and the SPP is 17.8 years. The main reason is in very high deterioration level of the most building elements and the larger share of costs is intended for the rehabilitation of the element's conditions (reflected in the coefficient $\mathrm{K}$ ). For example, investment in renovating of ceiling ( $\mathrm{RP} 1.3$ ) is equal to zero because it must be completely renewed for its further functioning. Consequently, complete refurbishment is economical for a typical timber preschool building, whereas step-by-step renovation is not.

b) Economic indicators for functional improvement measure

The increase of the purchase value of fixed assets model is used for evaluating functional improvement measures. The present value of the building is $€ 281722\left(539.22 € / \mathrm{m}^{2}\right)$ (Ministry of the Environment and Spatial Planning, 2018). With reference to measure of $I_{A}$ (RP 4), $I_{F}$ (RPs 6-10) and $I_{T F}$ (RPs 1-3), the increased value of the building is in total $€ 758567$ and $1162.63 € / \mathrm{m}^{2}$, respectively. Compared to the actual value of pre-school buildings, which were completely renovated, our values are corresponding, because the value of these buildings account from $1020 € / \mathrm{m}^{2}$ to $1560 € / \mathrm{m}^{2}$ (Ministry of the Environment and Spatial Planning, 2018; City Municipality Maribor, 2018).

\subsection{Discussion}

Energy renovation of a building shows that step-by-step refurbishment can result in energy savings; however, they are higher if they are joined together into a complex process. All steps of renovation should be carried out successively; still they are not necessary economically justified. In the case study for Kindergarten Mojca, the measure RP 1.3 proved to be the most energy and economically efficient. Even though the ceiling is the most critical 


\begin{tabular}{|c|c|c|c|c|c|c|c|c|c|c|c|c|c|c|c|c|c|c|c|c|c|c|c|c|}
\hline 总 & 灾 & $\begin{array}{lll}\infty & + & 0 \\
\stackrel{0}{0} & 0 & 0\end{array}$ & $\begin{array}{l}0 \\
\ddot{q}\end{array}$ & $\begin{array}{l}m \\
i \\
i\end{array}$ & $\stackrel{m}{p}$ & & & $\vec{b}$ & $\overrightarrow{\dot{m}}$ & & & & & & & $\begin{array}{l}\circ \\
\dot{a}\end{array}$ & $\overrightarrow{\mathrm{I}}$ & $\vec{v}$ & $\overrightarrow{\mathrm{b}}$ & & & & $\begin{array}{c}\infty \\
\\
-\end{array}$ & \\
\hline 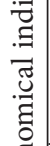 & 엉료 & 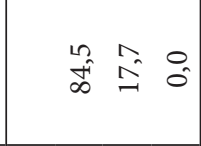 & $\begin{array}{l}0 \\
\hat{0}\end{array}$ & 亦 & $\begin{array}{l}\infty \\
+ \\
+\end{array}$ & & & $\begin{array}{l}\infty \\
\dot{0} \\
i \\
\sim\end{array}$ & $\begin{array}{c}\infty \\
\dot{\infty} \\
\underset{\sim}{\sim}\end{array}$ & & & & & & & ڤેे & & & & & & & & \\
\hline 氖 & 인 & 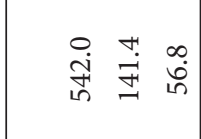 & $\begin{array}{c}\underset{i}{i} \\
\stackrel{i}{v}\end{array}$ & $\begin{array}{c}\infty \\
\dot{\infty} \\
\infty \\
m\end{array}$ & $\begin{array}{l}\dot{b} \\
\dot{\vec{v}} \\
\stackrel{\sim}{1}\end{array}$ & $\frac{\pi}{z}$ & $\frac{\pi}{z}$ & $\underset{\substack{\infty \\
\dot{\infty} \\
\sim}}{\sim}$ & 齐 & $\frac{\pi}{z}$ & $\frac{\pi}{\bar{z}}$ & $\frac{\pi}{z}$ & $\frac{\pi}{\bar{z}}$ & $\frac{\pi}{\bar{z}}$ & $\frac{\tilde{z}}{\bar{z}}$ & $\begin{array}{l}0 \\
\dot{0} \\
\text { in } \\
1\end{array}$ & $\begin{array}{l}\infty \\
\text { İ }\end{array}$ & \begin{tabular}{l|l} 
\\
$\dot{0}$
\end{tabular} & $\mid \begin{array}{c}\infty \\
\dot{\dot{d}} \\
\stackrel{\sim}{\sim}\end{array}$ & $\frac{\pi}{\bar{Z}}$ & $\frac{\pi}{z}$ & & ڤેे); & $\frac{\pi}{\bar{z}}$ \\
\hline $\begin{array}{l}\widehat{\sigma} \\
+ \\
\vec{\sigma} \\
0 \\
0\end{array}$ & 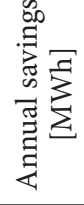 & 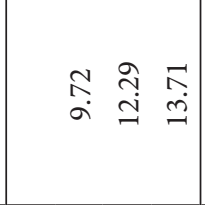 & $\stackrel{a}{a}$ & $\stackrel{?}{-}$ & $\begin{array}{l}m \\
\infty \\
\dot{b} \\
\dot{f}\end{array}$ & $\begin{array}{l}\stackrel{8}{\circ} \\
+ \\
i\end{array}$ & 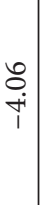 & $\begin{array}{l}\stackrel{J}{ \pm} \\
\pm \\
\end{array}$ & 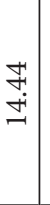 & 1 & 1 & 1 & 1 & 1 & & $\begin{array}{c}\vec{T} \\
\text { in } \\
\end{array}$ & 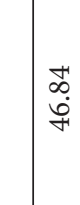 & 苔 & 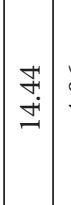 & 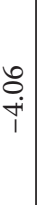 & 1 & & 文 & $\begin{array}{l}\stackrel{\bullet}{\circ} \\
\stackrel{+}{i}\end{array}$ \\
\hline 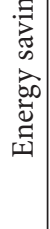 & 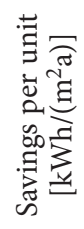 & 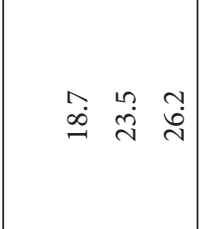 & $\begin{array}{l}10 \\
\infty \\
0 \\
0\end{array}$ & $\stackrel{\infty}{i}$ & $\hat{\infty}$ & $\stackrel{?}{\wedge}$ & $\stackrel{n}{\wedge}$ & $\vec{i}$ & $\vec{i}$ & 1 & 1 & 1 & 1 & 1 & & $\stackrel{m}{\Xi}$ & $\stackrel{\hat{\infty}}{\infty}$ & 1 & $\overrightarrow{\mathrm{i}}$ & $\stackrel{n}{\wedge}$ & 1 & & 罚: & $\stackrel{?}{\sim}$ \\
\hline & 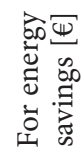 & 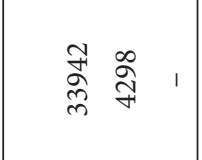 & $\begin{array}{l}\infty \\
\approx \\
\sim \\
\sim\end{array}$ & $\begin{array}{l}2 \\
\hat{2} \\
\infty \\
\infty\end{array}$ & 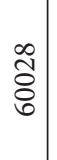 & 1 & & $\begin{array}{l}m \\
\substack{n \\
i n}\end{array}$ & $\begin{array}{l}m \\
\vec{n} \\
i \\
i n\end{array}$ & 1 & 1 & 1 & 1 & 1 & & 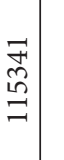 & 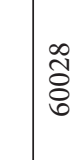 & i. & $\begin{array}{l}m \\
\vec{n} \\
\hat{n}\end{array}$ & 1 & 1 & & 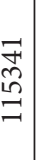 & I \\
\hline 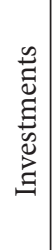 & 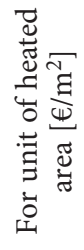 & 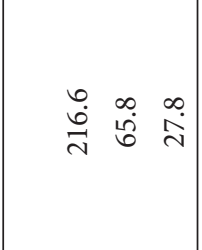 & $\underset{+}{+}$ & $\ddot{\leftrightarrow}$ & $\stackrel{\circ}{\stackrel{一}{F}}$ & $\begin{array}{l}\infty \\
\stackrel{\sim}{\sim} \\
\ddot{v}\end{array}$ & $\begin{array}{l}\infty \\
\stackrel{\sim}{\sim} \\
\stackrel{\sim}{N}\end{array}$ & $\begin{array}{l}\infty \\
+\infty \\
+\infty\end{array}$ & $\begin{array}{l}\infty \\
+ \\
\infty\end{array}$ & $\begin{array}{l}\dot{0} \\
\dot{f}\end{array}$ & 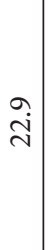 & $\begin{array}{c}1 \\
0 \\
i n\end{array}$ & $\begin{array}{l}\dot{b} \\
\dot{b} \\
\dot{m}\end{array}$ & $\stackrel{m}{\stackrel{\Xi}{=}}$ & $\begin{array}{l}\stackrel{n}{N} \\
\stackrel{\sim}{N}\end{array}$ & $\begin{array}{c}\vec{i} \\
\text { o } \\
-\end{array}$ & $\stackrel{g}{\vec{I}}$ & $\begin{array}{l}\overrightarrow{\dot{L}} \\
\overrightarrow{2} \\
\grave{2}\end{array}$ & \begin{tabular}{|l|}
$\infty$ \\
$\infty$ \\
$\infty$
\end{tabular} & $\begin{array}{l}\infty \\
\stackrel{\infty}{0} \\
\\
\end{array}$ & 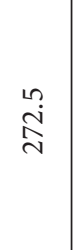 & & ڤે & $\begin{array}{l}\vec{i} \\
\text { ¿े } \\
\infty\end{array}$ \\
\hline & 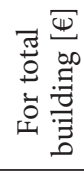 & 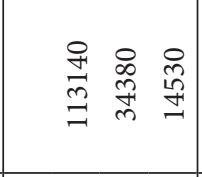 & $\stackrel{\vartheta}{\vec{F}}$ & $\begin{array}{l}\hat{n} \\
\hat{2} \\
\infty\end{array}$ & $\begin{array}{l}\vec{N} \\
\stackrel{\vec{N}}{N}\end{array}$ & 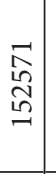 & 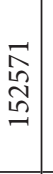 & 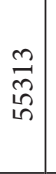 & $\begin{array}{l}m \\
\substack{n \\
i n} \\
i n\end{array}$ & $\begin{array}{l}0 \\
\underset{1}{\infty} \\
\underset{\sim}{\sim}\end{array}$ & $\begin{array}{l}\hat{\mathscr{o}} \\
\stackrel{\Xi}{\ddagger}\end{array}$ & $\begin{array}{l}\tilde{b} \\
\hat{\imath} \\
m\end{array}$ & 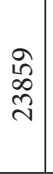 & $\begin{array}{l}\infty \\
\stackrel{0}{\infty} \\
\stackrel{1}{\wedge}\end{array}$ & $\begin{array}{l}m \\
\infty \\
\infty \\
\\
=\end{array}$ & 要 & 离 & 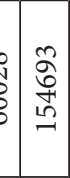 & $\mid$\begin{tabular}{l|l}
$m$ & \\
$n$ & \\
$n$ & \\
$n$ &
\end{tabular} & 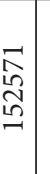 & $\begin{array}{l}m \\
\stackrel{\infty}{\infty} \\
\stackrel{1}{=}\end{array}$ & & 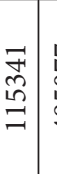 & 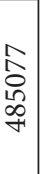 \\
\hline & $\approx$ & 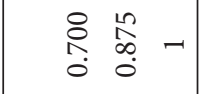 & $\mid \begin{array}{l}8 \\
\vdots \\
0 \\
0\end{array}$ & ঃ̊ & & $\begin{array}{l}0 \\
0 \\
0 \\
0 \\
0\end{array}$ & & $\begin{array}{ll}\stackrel{0}{n} \\
\stackrel{n}{-} \\
\end{array}$ & & 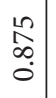 & - & $\left|\begin{array}{c}0 \\
\infty \\
\infty \\
0 \\
0\end{array}\right|$ & -1 & -1 & & & & & & & & & & \\
\hline & 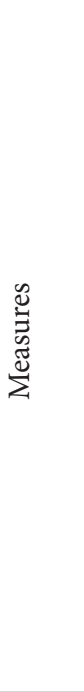 & 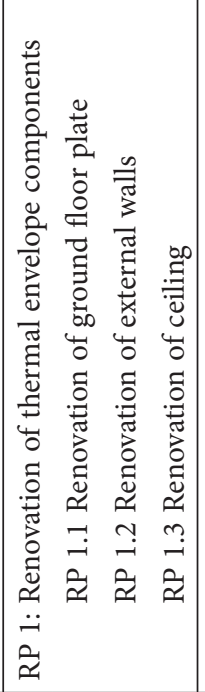 & 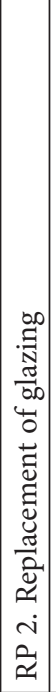 & 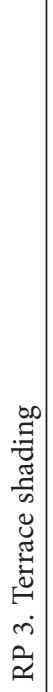 & 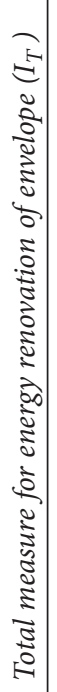 & 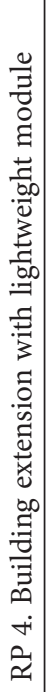 & 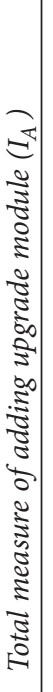 & 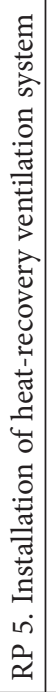 & 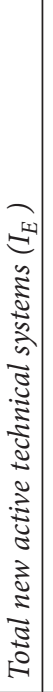 & 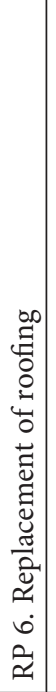 & 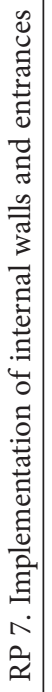 & 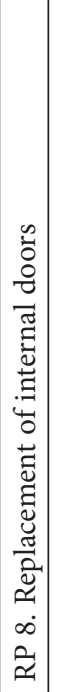 & 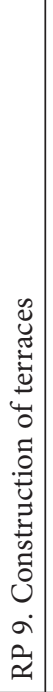 & 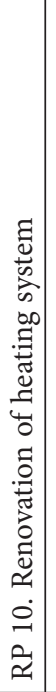 & 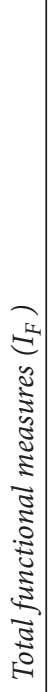 & 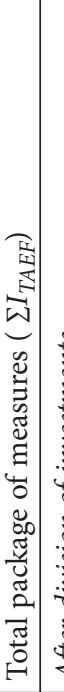 & 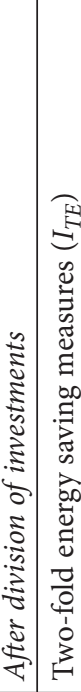 & 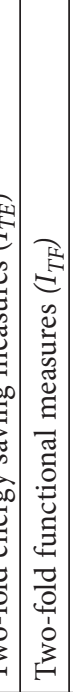 & 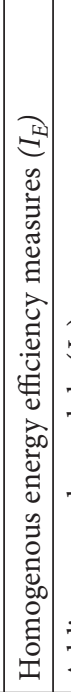 & 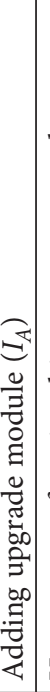 & 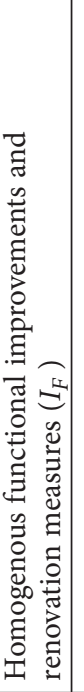 & 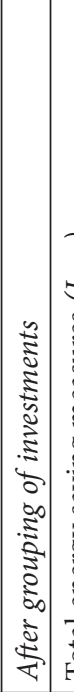 & , & 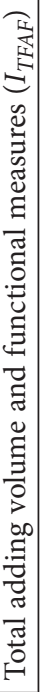 \\
\hline
\end{tabular}


element regarding energy losses, it presents the easiest renovation measure and the price of insulation is relatively low. The least energy efficient measure is RP 3 that contributes only to the overheating in the summer time. Despite the poor energy and cost efficiency results, this measure significantly contributes to the improvement of building functionality.

The indicated low level of economical inefficiency of the RP 1.1 and RP 5 measures resulted in an additional study. RP 1.1 is a very ineffective measure due to high investment costs including demolition of existing pavements, installation of thermal insulation, screed and floor finish. The highest share of investment costs includes installation of the thermal insulation, which is $150 € / \mathrm{m}^{2}$ (aerogel, $4 \mathrm{~cm}$ ), and which choice comes from the limitation of the clear ceiling height of playrooms, because the existing height is already on the permitted limit. In order to rationalize the measure, we suggest cheaper insulation, e.g. EPS $(\lambda=0.034 \mathrm{~W} /(\mathrm{mK})), 10 \mathrm{~cm}$ thick, which costs account for $15 € / \mathrm{m}^{2}$ only. The indicator $C C E$ would be $179.80 € / \mathrm{MWh}$ and $C C E_{T} 28.03 € / \mathrm{MWh}$ only. Therefore, the study results show that meeting all of the provisions of the regulation can lead to significant cost increase.

Furthermore, our second suggestion refers to the measure RP5 as central heat-recovery ventilation system that fulfils the requirements for high ventilation rates in playrooms, but results in high costs, especially due to the distribution of new ventilation elements. The rationalization could be achieved by local heat-recovery ventilation units, and this solution would cost only $€ 18000$, lowering the value of CCE measure RP 5 to $91.70 € / \mathrm{MWh}$. In our opinion, both suggestions do not impact the living quality but enable the investor to carry out the refurbishment in the rational scope of costs.

The overall results of the current study could be compared to study of Martinaitis et al. (2004), which describes the preschool building renovation and study of Martinaitis et al. (2007), dealing with the renovation of multifamily building. The values of the indicator CCE are comparable for individual measures of renovation and for the total energy saving measure $I_{T E E}$. The results for the school buildings renovation can be compared with the study of Stocker et al. (2015), where the measure effects are given by the cost/benefit parameter in $€ / \mathrm{kWh}$ year. The results for investment return are similar to the measures for cluster C.1 of renovation of the envelope thermal insulation and replacement of glazing. The latter is less favorable and depends largely on percentage of glass surface and use of innovative materials. Comparison with other studies is not beneficial, because they are focused in particular on different building types, structural systems, and economic indicators. However, it is possible to make some comparison on a general level of energy savings. Research by Congedo et al. (2016) shows that the cost-optimal solution reduces primary energy consumption by $85 \%$, while in our case $76 \%$ was achieved, however, our target level is not nZEBs. Stocker et al. (2015) find out that the building age and compactness have a high effect on the result on cost effectiveness; our case study also includes the importance of the building's age through the coefficient $(\kappa)$. In addition, the authors Niemelä et al. (2016) and Arumägi and Kalamees (2015) come to the similar conclusions as we, namely, the additional thermal insulation of external walls or deep energy renovation of the building's envelope alone without utilizing renewable energy production systems and considering the building service systems do not increase the cost-effectiveness. Importantly, the study by Arumägi and Kalamees (2015) refers to timber apartment buildings.

\section{Conclusions}

Refurbishment of the ageing building stock is tremendously important when following the principles of sustainable building and lowering energy demand in building operation. Moreover, the renovation of the existing educational buildings is one of the most current issue concerning public buildings across Europe. Educational buildings not only present an enormous potential for energy saving, but they also need modernization in terms of functionality, aesthetics and economic efficiency. Although the tools and methods to evaluate those advantages are already well-known, the renovations are not dealt with systematically and separately according to individual measures.

The presented integrated approach aims to provide step-by-step assessment of complex refurbishment projects of preschool buildings. The feasibility is established both for each step and for total package of measures, employing energy indicators and economic analysis. The benefits of the energy saving measures are explained with the economic indicators, by using the two-factor method, which takes into consideration the age of the building while standard model for determining the increased value of assets is used for investments in building renovation.

The suggested approach was implemented in the case study of the Kindergarten Mojca, presenting the typical preschool building in Slovenia. The refurbishment strategy improved the energy need for heating and cooling up to $76 \%$. An economical study proves the inefficiency of almost all measures if they are considered separately, but by grouping them, indicators of total energy saving measures are favorable. Moreover, the analysis results show that the level of reasonableness of the investment depends largely on the level of the desired energy renovation. In conclusion, not only the energy efficiency of the renovation is higher if it is complex, but also the economical viewpoint confirms feasibility of the renovation only in the case when it is not performed partially.

The suggested approach can be implemented in other preschool buildings in Slovenia and other countries with similarly typology of light timber buildings. Moreover, the systematic approach can serve as the basis for investors' decision making when choosing the concept of complex renovation strategy, based on integration of energy savings and economic efficiency according to individual steps and as total value. 


\section{Acknowledgements}

The authors acknowledge the financial support from the Slovenian Research Agency (research core funding No. P20129). Our thanks also go to EnergaP - Energy Agency of Podravje for data provision.

\section{Funding}

This work was supported by research funding No. P2-0129 "Development, modelling and optimization of structures and processes in civil engineering and traffic" of the Slovenian Research Agency.

\section{Author contributions}

Ideally, people who contributed to the work are listed in this section along with their contributions: Nataša Šuman, Maja Žigart, Miroslav Premrov and Vesna Žegarac Leskovar conceived the study and were responsible for the development of the data analysis. Nataša Šuman and Maja Žigart were responsible for design, data collection and data analysis. Nataša Šuman, Miroslav Premrov and Vesna Žegarac Leskovar were responsible for data interpretation.

\section{Disclosure statement}

The authors state that there are no competing financial, professional, or personal interests involving other parties in this research.

\section{References}

Arumägi, E., \& Kalamees, T. (2015). Analysis of energy economic renovation for historic wooden apartment buildings in cold climates. Applied Energy, 115, 540-548. https://doi.org/10.1016/j.apenergy.2013.10.041

Baker, L., \& Bernstein, H. (2012). The impact of school buildings on student health and performance: a call for research authors. McGraw-Hill Research Foundation, Center for Green Schools. U.S. Green Building Council. Retrieved from http://www.centerforgreenschools.org/impact-school-buildings-student-health-and-performance

Becchio, C., Ferrando, D. G., Fregonara, E., Milani, N., Quercia, C., \& Serra, V. (2016). The cost-optimal methodology for the energy retrofit of an ex-industrial building located in Northern Italy. Energy and Buildings, 127, 590-602.

https://doi.org/10.1016/j.enbuild.2016.05.093

Bonakdar, F., Dodoo, A., \& Gustavsson, L. (2014). Cost-optimum analysis of building fabric renovation in a Swedish multistory residential building. Energy and Buildings, 84, 662-673. https://doi.org/10.1016/j.enbuild.2014.09.003

Buildings Performance Institute Europe (BPIE). (2011). Europe's buildings under the microscope. Brussels: Buildings Performance Institute.

Causone, F., Carlucci, S., Moazami, A., Cattarin, G., \& Lorenzo, P. (2015). Retrofit of a kindergarten targeting zero energy balance. Energy Procedia, 78, 991-996. https://doi.org/10.1016/j.egypro.2015.11.039

City Municipality Maribor. (2018). City Council, materials. Retrieved from http://www.maribor.si/podrocje.aspx?id=23 (in Slovenian).
Congedo, P. M., D’Agostino, D., Baglivo, C., Tornese, G., \& Zacà, I. (2016). Efficient solutions and cost-optimal analysis for existing school buildings. Energies, 9(10), 851.

https://doi.org/10.3390/en9100851

Corgnati, S. P., Ansaldi, R., \& Filippi, M. (2009). Thermal comfort in Italian classrooms under free running conditions during mid seasons: Assessment through objective and subjective approaches. Building and Environment, 44(4), 785-792. https://doi.org/10.1016/j.buildenv.2008.05.023

Corgnati, S. P., Filippi, M., \& Viazzo, S. (2007). Perception of the thermal environment in high school and university classrooms: Subjective preferences and thermal comfort. Building and Environment, 42(2), 951-959. https://doi.org/10.1016/j.buildenv.2005.10.027

Environmental Agency of the Republic of Slovenia. (2018). Portal ARSO. Retrieved from http://meteo.arso.gov.si/uploads/ probase/www/climate/image/sl/by_variable/solar-radiation/ mean-bright-sunshine-duration_year_81-10.png

European Commission. (2010). PPP. Energy-efficient buildings. Multi-annual roadmap and longer term strategy. Brussels: European Commission.

European Parliament, \& Council of the European Union. (2002). Directive 2002/91/EC of the European Parliament and of the Council of 16 December 2002 on the energy performance of buildings. Retrieved from https://eur-lex.europa.eu/legal-content/EN/TXT/?uri=CELEX\%3A32002L0091

European Parliament, \& Council of the European Union. (2010). Directive 2010/31/EU of the European Parliament and of the Council of 19 May 2010 on the energy performance of buildings. Retrieved from https://eur-lex.europa.eu/legal-content/ EN/TXT/?qid=1534941584761\&uri=CELEX:32010L0031

Eurostat. (2010). Eurostat yearbook 2010. Retrieved from https://ec.europa.eu/eurostat/web/products-statistical-books/-/ KS-CD-10-220

Feist, W. (2013). Passive house planning package PHPP, energy balance and passive house design tool for quality approved. Passive Houses and EnerPHit retrofits, Version 8.

Ivačič, A., Jashanica, K., Lešnik, M., \& Stopar, A. (2014). Sustainable concepts of building design: Conceptual renovation project of kindergarten Pobrežje, unit Mojca. University of Maribor, Faculty of Civil Engineering, Maribor.

Konstantinou, T., \& Knaack, U. (2013). An approach to integrate energy efficiency upgrade into refurbishment design process, applied in two case-study buildings in Northern European climate. Energy and Buildings, 59, 301-309. https://doi.org/10.1016/j.enbuild.2012.12.023

Kuusk, K., Kalamees, T., Link, S., Ilomets, S., \& Mikola, A. (2017). Case-study analysis of concrete large-panel apartment building at pre- and post low-budget energy-renovation. Journal of Civil Engineering and Management, 23(1), 67-75. https://doi.org/10.3846/13923730.2014.975741

Martinaitis, V., Kazakevicius, E., \& Vitkauskas, A. (2007). A twofactor method for appraising building renovation and energy efficiency improvement projects. Energy Policy, 35(1), 192201. https://doi.org/10.1016/j.enpol.2005.11.003

Martinaitis, V., Rogoža, A., \& Bikmanien, I. (2004). Criterion to evaluate the "two-fold benefit" of the renovation of buildings and their elements. Energy and Buildings, 36(1), 3-8. https://doi.org/10.1016/S0378-7788(03)00054-9

Meteotest. (2018). Meteonorm 7.1, Software.

Mijakowski, M., \& Sowa, J. (2017). An attempt to improve indoor environment by installing humidity-sensitive air inlets in a naturally ventilated kindergarten building. Building and Environment, 111, 180-191. https://doi.org/10.1016/j.buildenv.2016.11.013 
Ministry of Education, Science and Sport. (2018). List of kindergartens. Retrieved from http://www.mizs.gov.si/si/delovna podrocja/direktorat_za_predsolsko_vzgojo_in_osnovno_solstvo/predsolska_vzgoja/ (in Slovenian).

Ministry of Infrastructure and Ministry of Public Administration. (2015). Long-term strategy for mobilising investments in the energy renovation of buildings (DSEPS). Retrieved from http://www.energetika-portal.si/dokumenti/strateski-razvojni-dokumenti/dolgorocna-strategija-za-spodbujanje-nalozbenergetske-prenove-stavb/ (in Slovenian).

Ministry of Infrastructure. (2018). Energy portal. Retrieved from http://www.energetika-portal.si/javne-objave/objava/?tx t3javnirazpis_pi1\%5Bshow_single\%5D=937 (in Slovenian).

Ministry of the Environment and Spatial Planning, The Surveying and Mapping Authority of the Republic of Slovenia. (2018). Portal Prostor. Retrieved from http://www.e-prostor.gov.si/ (in Slovenian).

Ministry of the Environment and Spatial Planning. (2010). Technical guidelines TSG-1-004:2010 Efficient use of energy. Retrieved from http://www.mop.gov.si/si/delovna_podrocja/ graditev/prirocniki_navodila_smernice/ (in Slovenian).

Niemelä, T., Kosonen, R., \& Jokisalo, J. (2016). Cost-optimal energy performance renovation measures of educational buildings in cold climate. Applied Energy, 183, 1005-1020. https://doi.org/10.1016/j.apenergy.2016.09.044

Norris, M., \& Shiels, P. (2004). Regular national report on housing developments in European countries. Synthesis Report. Dublin: The Housing Unit.

Official Gazette of the Republic of Slovenia No. 20/2004, 18/2011. Rules on standards for the maintenance of apartment buildings and apartments (in Slovenian).

Official Gazette of the Republic of Slovenia No. 73/2010, 75/05, $33 / 08,126 / 08,47 / 10,47 / 13,74 / 16$ in 20/17. Rules on standards and minimal technical conditions for kindergarten premises and equipment (in Slovenian).

Official Gazette of the Republic of Slovenia No. 95/2015, 71/2016, 23/2017. Slovenian accounting standards (in Slovenian).

Official Gazette of the Socialist Federal Republic of Yugoslavia No. 35/70. Rules on technical measures and conditions for protection of buildings (in Serbo-Croatian).

Pagliano, L., Carlucci, S., Causone, F., Moazami, A., \& Cattarin, G. (2016). Energy retrofit for a climate resilient child care centre. Energy and Buildings, 127, 1117-1132.

https://doi.org/10.1016/j.enbuild.2016.05.092

Pereira, L. D., Raimondo, D., Corgnati, S. P., \& da Silva, M. G. (2014). Assessment of indoor air quality and thermal comfort in Portuguese secondary classrooms: Methodology and results. Building and Environment, 81, 69-80. https://doi.org/10.1016/j.buildenv.2014.06.008

Petersen, S., \& Svendsen, S. (2012). Method for component-based economical optimisation for use in design of new low-energy buildings. Renewable Energy, 38(1), 173-180. https://doi.org/10.1016/j.renene.2011.07.019

Pikas, E., Kurnitskic, J., Liiasc, R., \& Thalfeldt, M. (2015). Quantification of economic benefits of renovation of apartment buildings as a basis for cost optimal 2030 energy efficiency strategies. Energy and Buildings, 86, 151-160. https://doi.org/10.1016/j.enbuild.2014.10.004

Poel, B., Cruchten, G., \& Balaras, C. A. (2007). Energy performance assessment of existing dwellings. Energy and Buildings, 39, 393-403. https://doi.org/10.1016/j.enbuild.2006.08.008

Premrov, M., Žigart, M., \& Žegarac Leskovar, V. (2017). Influence of the building geometry on energy efficiency of timber-glass buildings for different climatic regions. Journal of Applied Engineering Science, 15, 529-539.

https://doi.org/10.5937/jaes15-15256

Premrov, M., Žigart, M., \& Žegarac Leskovar, V. (2018). Influence of the building shape on the energy performance of timberglass buildings located in warm climatic regions. Energy, 149, 496-504. https://doi.org/10.1016/j.energy.2018.02.074

Salvalai, G., Malighetti, L. M., Luchini, L., \& Girola, S. (2017). Analysis of different energy conservation strategies on existing school buildings in a Pre-Alpine Region. Energy and Buildings, 145, 92-106.

https://doi.org/10.1016/j.enbuild.2017.03.058

Semprini, G., Marinosci, C., Ferrante, A., Predari, G., Mochi, G., Garai, M., \& Gulli, R. (2016). Energy management in public institutional and educational buildings: The case of the school of engineering and architecture in Bologna. Energy and Buildings, 126, 365-374.

https://doi.org/10.1016/j.enbuild.2016.05.009

Špegelj, T., Žegarac Leskovar, V., \& Premrov, M. (2016). Application of the timber-glass upgrade module for energy refurbishment of the existing energy-inefficient multi-family buildings. Energy and Buildings, 116, 362-375.

https://doi.org/10.1016/j.enbuild.2016.01.013

Stankevičius, V., Karbauskaitè, J., Burlingis, A., Šadauskienè, J., \& Morkvènas, R. (2014). Expanding the possibilities of building modernization: Case study of Lithuania. Journal of Civil Engineering and Management, 20(6), 819-828.

https://doi.org/10.3846/13923730.2014.929599

Stankovic, D., Tanic, M., Kostic, A., Timotijevic, M., Jevremovic, L., Jovanovic, G., Vasov, M., \& Sokolovskii, N. (2015). Revitalization of preschool buildings: A methodological approach. Procedia Engineering, 117, 723-736. https://doi.org/10.1016/j.proeng.2015.08.201

Stocker, E., Tschurtschenthaler, M., \& Schrott, L. (2015). Costoptimal renovation and energy performance: Evidence from existing school buildings in the Alps. Energy and Buildings, 100, 20-26. https://doi.org/10.1016/j.enbuild.2015.04.005

Tahsildoost, M., \& Zomorodian, S. Z. (2015). Energy retrofit techniques: An experimental study of two typical school buildings in Tehran. Energy and Buildings, 104, 65-72. https://doi.org/10.1016/j.enbuild.2015.06.079

Tanic, M., Stankovic, D., Nikolic, V., Nikolic, M., Kostic, K., Milojkovic, A., Spasic, S., \& Vatin, N. (2015). Reducing energy consumption by optimizing thermal losses and measures of energy recovery in preschools. Procedia Engineering, 117, 919-932. https://doi.org/10.1016/j.proeng.2015.08.179

Yun, H., Nam, I., Kim, J., Yang, J., Lee, K., \& Sohn, J. (2014). A field study of thermal comfort for kindergarten children in Korea: An assessment of existing models and preferences of children. Building and Environment, 75, 182-189. https://doi.org/10.1016/j.buildenv.2014.02.003

Žegarac Leskovar, V., \& Premrov, M. (2011). An approach in architectural design of energy-efficient timber buildings with a focus on the optimal glazing size in the south-oriented façade. Energy and Buildings, 43, 3410-3418. https://doi.org/10.1016/j.enbuild.2011.09.003

Žegarac Leskovar, V., \& Premrov, M. (2013). Energy-efficient timber-glass houses. Springer Verlag. https://doi.org/10.1007/978-1-4471-5511-9

Žegarac Leskovar, V., Premrov, M., \& Kitek Kuzman, M. (2012). Energy-efficient renovation principles for prefabricated timber-frame residential buildings. Drvna industrija, 63(3), 159168. https://doi.org/10.5552/drind.2012.1127 